\title{
Editorial: Self Invested Personal Pension schemes - The flexible future of personal pensions?
}

Back in 1963 when the author first started work in the investment industry, around 6 per cent of the UK stockmarket was owned by pension funds. By contrast, nearly 60 per cent was in the hands of private individuals. Of course, the market was a lot smaller in those days. It was also viewed as more of a casino by many investors. The late George Ross-Goobey was still in charge of the Imperial Tobacco Companies pension funds, having not much more than a decade earlier persuaded the trustees that equities were the most appropriate long-term home for pension fund assets. He was ahead of his time and the rise of the power of pension funds in stockmarket terms was only just beginning.

Then the emphasis was on occupational schemes - and ones that delivered a benefit based on final salary. In this the UK was enlightened. The welfare state was, after all, barely 15 years old. Beveridge's aim had been to deliver to the population of this country a guaranteed minimum pension which would ensure a degree of comfort in retirement. This was a less generous offer than it appeared. A retirement age of 65 committed the country to paying for an average of just ten months, so far as the life expectation of the working man was concerned. But pensions were to become an important part of the package with which companies enticed employees, particularly those straight from university. Enlightened businesses used the offer of attractive pensions as a means of persuading gifted people to work for them and, more importantly, to stay.

It took less than a quarter of a century for the picture to change dramatically. Not only had the power of pension funds in the stockmarket grown dramatically (it is estimated they now own nearly 40 per cent of the value of London shares), but it became increasingly clear that greater longevity and changes in working practices would necessitate a radical re-think of pensions provision. With people living longer, many of the assumptions that were made at the time the national state pension was established became untenable. In particular, governments were expecting to find funding a pension that was adequate to cover people's normal living costs in retirement a burden which would grow to the point of intolerability. Not only would the level of cover provided by the State have to decline in relative terms, but individuals would need to be encouraged, perhaps through some form of compulsion, to make their own arrangements so that the State would not have the cost of looking after them once they stopped work. With a falling birth rate, and every likelihood that life expectancy would continue to increase, it became inevitable that the percentage of the population that were 
over the retirement age would steadily increase, supported by a dwindling workforce, whose tax take would eventually be insufficient to cover state pension costs.

The second driving force, the gradual erosion of the expectation of a working life spent in continuous employment with a single company, also made a massive difference to the way in which an individual's occupational pension scheme should be provided. It had not been unusual in the past for early leavers from a company's pension scheme effectively to fund the pensions of those who remained employed, through poor transfer values. Greater openness in the way in which occupational schemes' assets were allocated to individual members and the growth of the personal pensions market made the mobility of labour that much easier. But in turn it created potential and, in some instances, very real problems, most notably when individuals transferred from occupational schemes into personal pensions in the interest of flexibility. The final costs of the so-called 'Pensions Mis-selling' scandal have yet to be counted.

When Nigel Lawson announced that the individual saver into a retirement fund should have greater freedom to exercise control over the investment policy back in 1989, he must have had the massive success of the personal pension policies that were even then taking off in the USA. The Individual Retirement Accounts, now better known as $401 \mathrm{k}$ policies - perhaps because of the unfortunate sequence of initials they enjoy - were introduced in the early 1980s but were already beginning to make a real impact on the American savings market. It is not fanciful to suggest that their growth has been a prime engine in driving the spectacular stockmarket performance that has taken place in the USA. Of particular importance, though, is the fact that more and more companies have these personal pension plans as part of their employment package, making it easy for people to buy into the concept. This, coupled with rising share values, has helped create an enormous pool of invested assets that will, hopefully, ensure that middle America enjoys comfortable retirement.

In this country the nearest equivalent to a $401 \mathrm{k}$ policy is, perhaps, the Self Invested Personal Pension, or SIPP. Launched a little over ten years ago, SIPPs were slow to get off the ground, but are now beginning to attract money rapidly. Indeed, Winterthur, one of the principal administrators of SIPP schemes, has forecast that the SIPP market, presently estimated at $\mathcal{K} 12.5 \mathrm{bn}$ of investable assets, could grow to $\mathcal{E}_{175} \mathrm{bn}$ over the course of the next decade. That is about a quarter of the size of the present pensions market - but that remains dominated by occupational, defined contribution schemes.

Part of the reason that SIPPs were slow to get off the ground is because they are a little daunting to the individual in the way in which they effectively throw back the responsibility for investment performance to the person funding the pension. However, a growing professional management market should ensure that a good degree of choice is available and inevitably people will start to understand this new approach better. Nevertheless, one should not underestimate the effect that the changing face of the pensions market is likely to have for Independent Financial Advisers. Few individuals would in the past have considered taking out a personal pension without receiving some form of advice. But such is the focus on making people understand the importance of pensions that people are more questioning than they have been in 
the past. Moreover, the growth of transactions over the Internet could allow people to make decisions as important as saving for their retirement by conducting their own research and reaching a decision themselves, without the input of an adviser. This has the merit of reducing the cost of the pension to the purchaser, although it must be stressed that there will be many instances in which sound and ongoing advice will not just be desirable, but is likely to prove most important.

The introduction of the Stakeholder Pension is likely to accelerate the new paradigm for buying pensions. With Stakeholder capped at 1 per cent for charges, there is little margin for the provision of advice. Indeed, it seems inevitable that, for Stakeholder to work properly, it will largely have to be distributed electronically, saving costs all along the line. While this is unlikely to cause too much of a problem to the new generation of computer-literate individuals, there will be many who will find Stakeholder inaccessible as a consequence.

It is very difficult to determine quite what impact Stakeholder will have, but it could be significant, particularly at the lower end of the market. Equally, for those with the ability to save more into their pension scheme, the SIPP market is likely to prove increasingly attractive, squeezing the market for other types of personal pensions quite significantly. However, those Independent Financial Advisers who develop their skills in advising on more substantial pension cases should ensure that they have a profitable future while, even with Stakeholder, the ability to offer generic advice, perhaps to affinity groups, or to facilitate purchases electronically, will become increasingly important.

If the author appears to be drawing an analogy between SIPPs and Stakeholder, then no apologies are offered. Many of the standards that the Government will insist are applied to Stakeholder should of necessity apply also to Self Invested Personal Pensions. The fact that SIPP cases are likely to be more substantial does not alter the need to ensure that value for money is delivered, while the flexibility of the SIPP — probably its most important attribute — is something that will undoubtedly be a feature of the Stakeholder pension. This flexibility in SIPPs can be found in a number of different ways. With pressure growing for an end to the compulsory annuity purchase at 75 , income drawdown is likely to become an increasing feature of pension planning. SIPPs, too, lend themselves to inheritance tax planning, to providing an income for a surviving spouse and to ensuring that the most complex of working arrangements, such as choosing to earn through consultancy work after retirement and thus not needing to draw a full pension, can be catered for.

The SIPP market is thus both potentially very wide and certainly most interesting, both from the point of view of the adviser and the investment manager. Clearly, SIPPs are likely to have a useful role to play for the selfemployed - or to anyone else who is able to put a free-standing pot of money aside for retirement. In particular, the ability to vary contributions will be valuable for those whose earnings patterns may be erratic. One immediately thinks of high earners in the city whose working life might be shortened through corporate activity or simply burning out. One market that is also expected to develop quite swiftly is that of the occupational scheme transfer. Again, this will be particularly attractive to those contemplating partial retirement, but who nevertheless would be expected to take their usual pension if they remained 
in the company scheme. Opting to transfer the value of their pension into a SIPP widens their options. It also has the merit of creating a capital sum which can be used in inheritance tax planning — another strong argument in favour of abolishing compulsory annuity purchase.

If SIPPs look to become a more important component in the personal pensions market, then establishing the correct investment strategy will clearly be of paramount importance. This, of course, is easy to say but less easy to put into practice, particularly as investment patterns are changing rapidly at present. Some personal pension plans adopt a fairly simplistic approach to investment planning, presumably using the number of years to normal retirement date to govern the asset mix. Perpetual has just such an approach, with a personal pension that increases the exposure to bonds and cash the closer the investor gets to retirement.

At least a SIPP enjoys that added flexibility which means the investment strategy can be varied not only to take account of individual circumstances, but also the themes that are running through the market at any given time. This flexibility is particularly important at a time of low inflation and low annuity rates. While the annuity position might improve if the rules are changed to allow pension funds to purchase corporate bonds, rather than solely gilts, to maintain their Minimum Funding Requirement, the inverted yield curve is creating major problems for insurance companies as they endeavour to satisfy the demand for annuities. Against this background income drawdown seems a very attractive option. There are disadvantages as well as advantages, the most notable being the lack of guarantee that one has to accept through going down this route. But the ability to retain ownership of the capital of the pension fund is a powerful motive. Varying the amount of income and frequency with which it is paid can also be useful for wealthier retirees. It is quite possible to satisfy the Inland Revenue's requirements in income drawdown and yet give oneself an income holiday for a particular year if it is warranted by tax planning.

Moreover, despite the risks associated with using the income drawdown approach, it does provide a degree of protection for both inflation and providing for a wife (or husband) which are costly to preserve using the conventional annuity route. As an example, a male aged 65 endeavouring to maintain some protection against inflation and to ensure that his wife retains her pension rights on his death will find the actual annuity rate halving once the cost of all these benefits has been deducted.

The author remains convinced that, ultimately, the age 75 will be swept aside as the Government realises that even greater flexibility in pension planning is needed. Self Invested Personal Pensions, with their considerable flexibility, can only benefit from the changes that are taking place. People may find they are all larger investors in the stockmarket in the future - by virtue of their pension fund holdings; and that may be a bad thing. As Thorstein Veblen wrote just 100 years ago in 'The Theory of the Leisure Class', 'Wealth is now itself intrinsically honourable and confers honour on its possessor'.

Brian Tora

Head of Asset Management Greig Middleton \& Co. Ltd 